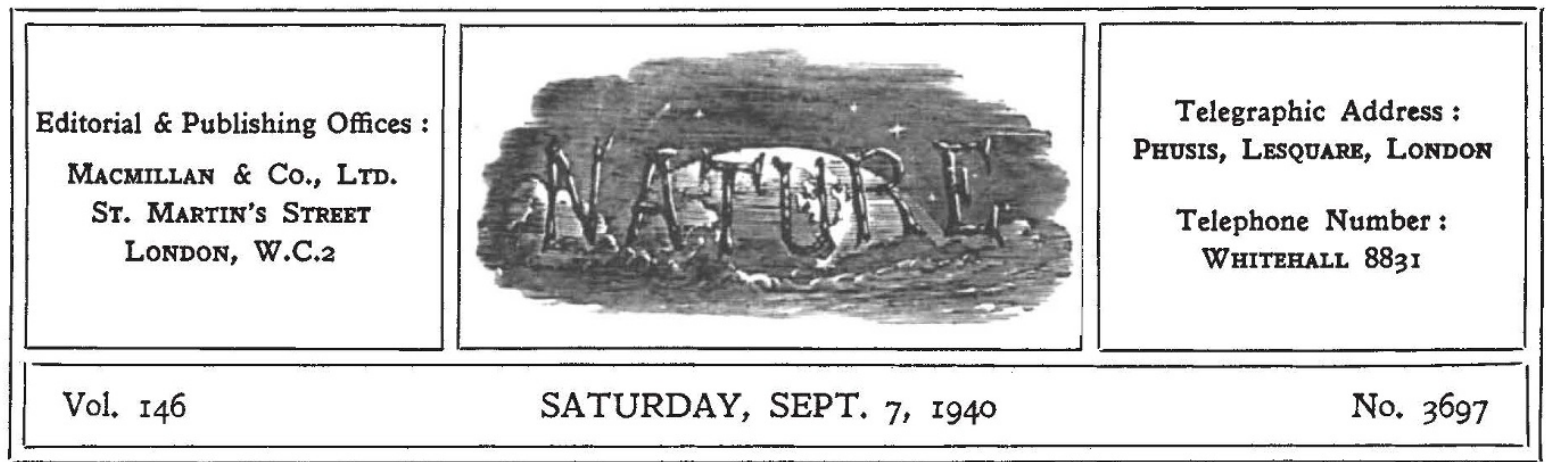

\title{
LEADERSHIP IN RECONSTRUCTION
}

$\mathrm{O}^{\mathrm{N}}$

NE of the most encouraging features of Prof.

K. Mannheim's admirable study "Man and Society in an Age of Reconstruction" is the vista he opens out before us of the possibilities in the use of the study of society along scientific lines in the actual task of reconstruction. With a right conception of planning and the wise use of the appropriate technique, it should be possible to plan and to build a social order in which are preserved the freedom essential for creative work and moral and intellectual development and the harmony essential if men are to live together in an ordered society.

Prof. Mannheim's conception of planning, as of freedom, is dynamic. Man's needs change no less than the form in which those needs are expressed or served. Our task in this time of crisis and change is the dynamic one of bringing creative thought and constructive effort to bear, so that the organization of society is not left to chance or irrational forces but guided with the inspiration which comes from bringing all our available scientific energy and insight to bear on the understanding of the situation and the control of the determining factors.

The records of the War of 1914-18 show that we were able to look forward, even amid the preoccupations of some of its darkest years, and to plan and build for the future with such measures as the Education Act, the Representation of the People Act, the Sex Disqualification (Removal) Act and others of a like type, to which an admirable broadsheet of PEP (Political and Economic Planning) has directed attention. To-day the disturbance to the social and economic life of the country is even more profound. At the same time, the opportunities of reconstruction are opening up before us still more freely and widely. Democracy has a greater chance than ever of demonstrating its enduring value, its link with the imperishable elements in our moral heritage, by taking the expedients temporarily forced upon us by war, and with the necessary adjustments building them into the permanent structure of our mode of life. In the same way, advantage can be taken of the opportunity afforded by the crumbling of prejudice or privilege under the demands of war economy to make advances which in peace-time have long been delayed by vested interests. In the working out of new and dynamic conceptions of freedom and discipline, a final reply can be given to the totalitarian taunt of effete or decaying democracy.

The elaboration of a complete programme at the present time is both premature and undesirable. To arouse a general awareness of the opportunities, to stimulate a creative and adventurous outlook, so that in our thinking about immediate problems there is awareness and subconscious, if not deliberate, thought about the way in which they can be linked up with the post-war problems, is sufficient. If only this be done, a vital part of the preparation for further advance will have been carried out, the lack of which was a main hindrance after 1918. Without the adequate preparation of public opinion, the creation of a Ministry of Reconstruction by itself could achieve little. New forms of freedom will always be rejected until, as Mannheim points out, men have been prepared spiritually for them and ceased to think in terms of an earlier phase of social existence.

Reference has been made from time to time in these columns to some of the possibilities in regard to nutrition and health and the standard of living which might flow from a far-sighted food policy, embracing production, distribution and storage, 
agriculture and horticulture, initiated primarily to meet our war-time requirements. Another complex problem which should not be approached from the point of view of war effort alone is the most effective utilization of man-power in production and in the armed forces. The immense powers of the Minister of Labour and the Minister of Supply in regard to the control and dilution of labour, the utilization of skilled or professional labour of all kinds, the introduction of women and of part-time labour, the deflection of production and labour from non-essential industries, if wisely exercised in connexion with adequate short-term and long-term training policies, should makean important contribution to the solution of the unemployment problem.

This point is the central theme of a recent pamphlet "Post-War Poverty and Unemployment can be Prevented" by T. W. Wyatt and D. Caradog Jones (J. Woolman and Sons, Dacre Street, Birkenhead. $6 d$.). If economic depression and unemployment, can be temporarily. cured by war, a better and more radical cure must be possible under conditions of peace. Pointing out that to all intents and purposes the War is being paid for as it is waged, that under war conditions money is not the essential consideration, and that the great mass of production and service utilized for war purposes is supplied in Great Britain, the authors argue that if the situation is properly handled by the Government, a repetition of the economic depression and serious unemployment which followed the War of 1914-18 is not inevitable. It should be possible, when peace comes, to change over from war production to peace production, and so make use of our vastly increased capacity for creating new wealth.

To utilize effectively the immense potential power of production, a carefully thought-out plan is essential, co-ordinating all forms of industrial activity. Messrs. Wyatt and Caradog Jones consider that their aims can be achieved under the present economic system, where private enterprise has free play, subject only to the appropriate Government control. Demobilization, for example, should be carried out gradually and systematically, and all who have given their service to the country should continue to receive full pay until they are absorbed again into industry. The aim of those directing affairs should be so to adjust spending, whether by taxation or rationing, that supply keeps step as nearly as possible with demand. If private enterprise proves insufficient within a reasonable time to absorb all demobilized men and women and to maintain consumption, public works should be instituted. There is no limit to work of this kind that might be done. Roads and transport, forestry, town- and country-planning, water supply, and electric power distribution provide innumerable opportunities, and no consideration of cost should interfere with the Government programme, provided only that the work undertaken is thoroughly and efficiently executed.

Discussing the possibility of inflation, Messrs. Wyatt and Jones believe that an expansion of currency for such purposes is safe until our resources of man-power and machinery are fully and adequately employed. They make the further point that in this new order we must school ourselves to a greater willingness to contribute gladly from our surplus income for social purposes. A planned economy is also essential because in due time it will be necessary to regulate the speed of production. The primary aim of the Government should be to adjust its financial policy so that an expanding market is always available for the goods produced. They further consider that by a systematic and continuous increase in production we can raise the standard of living all round.

To meet the new situation intelligent organization and administrative ability are the gifts which will be most in demand. Skilled workers will also be required for key positions ; they may not be immediately available in sufficient numbers, and some may have to be trained. If, however, the problem is attacked on scientific lines and an honest attempt made to utilize fully the available resources, these needs can be met.

A constructive postscript to the pamphlet by J. R. Bellerby suggests that the post-War period will be marked by five fairly distinct phases. An initial phase of momentary depression is likely to be followed rapidly by one in which labour is fully employed in capital reconstruction, and Government action in this phase is of the utmost importance. The transformation of the Ministry of Supply into a Ministry of Reconstruction with specific powers to guarantee priority in the requisition of raw materials, machinery and services for the most vital consumptive goods, to control demobilization, adjust the flow of gratuity payments to the Forces, and postpone public or semi-public works, would be vital contributions. This phase would, if managed well, merge into a third phase in which there would be no serious shortage of essential consumable goods. In this stage an additional amount of deferred pay and gratuities to the Forces could be released. These three phases, 
throughout which the national budget is likely to remain unbalanced, would be followed by a fourth phase, characterized by a lack of consuming power, and at this stage the Government would have in reserve all the public and semi-public works it had been able to postpone. The real post-War test, however, would come at the fifth stage, when these schemes had been exhausted and the true remedy must lie in the unconventional and the costly. We have to learn the methods by which a controlled economy can be worked, and create a race of men and women as competent to administer British industry in the general interest as their grandfathers were to administer the other functions of the State.

We must, it is true, temper this note of optimism and hopeful view by the realization that there are still backward and recalcitrant elements in our midst. Even in regard to food, it is a damning indictment of the management of hospitals and other institutions, calling for immediate and drastic action, that the Ministry of Food should need even to issue a suggestion that the present abundant supplies of fresh fruit and vegetables should be used in place of drawing on reserves of canned supplies. Widespread uneasiness has also been caused by Mr. Bevin's recent disclosure in the House of Commons that some employers have failed to respond to his appeal regarding training of men at the higher and lower levels of skill. The reluctance of the Government to use its powers of compulsion has been the subject of as much criticism as its apparent absence of any clear policy in regard to the introduction and training of women, the industries or sources from which they are to be drawn and the equally important problem of utilizing on war work the labour compulsorily evacuated or transferred from defence areas.

These disturbing signs are evidence that one of our greatest tasks to-day is that of finding leadership of the requisite competence and integrity in politics, in industry, in finance, in art, in journalism, in the Civil Service. The raw material of leadership is as abundant as ever, but we can no longer claim that our social system is selecting and throwing up ability with the same outstanding efficiency and success as in the past. For this reason alone a thorough overhaul of our educational system is a vital necessity.

A prominent feature of the present situation is indeed that in general outlook the community is often far ahead of its leaders. In one field after another, in finance, in criticism of the budget or of labour, in the utilization of part-time services, alike for munitions production or in civil defence, the cry is that enough is not being demanded of us, insufficient guidance is being given, and inefficient use made of willing service. This feature has implications the importance of which can scarcely be overstressed.

In the planning to which we have referred we are in essence outlining a Bill of Human Rights embodying the minimum requirements for decent living, including the basic guarantees of the individual, such as freedom of speech, writing and religion, the right to a fair trial, the subordination of all government to the rule of law, the establishment of minimum standards of housing, food, education and medical care; and the provision of security against unemployment, accident, widowhood and old age. The presence of this widespread spirit of service in the community is one of the strongest safeguards against any undermining of the sense of individual social responsibility in the: process, which Prof. Mannheim remarks must be carried out before planning can work smoothly, of abolishing the more blatant differences in wealth and opportunity.

It is of vital importance that this spirit of service should be canalized into some more permanent form. The counterpart to a Bill of Human Rights should be, as a recent leading article in The Economist has suggested, a Bill of the Duties which the citizen owes to the community of which he is a member. The minimum of rights will be the more cherished if it is paid for by a minimum of duties. Out of the fabric of relations involved in civil defence and the like, we may well evolve a new conception of the 'good neighbour'. We must now think of the community, the commonwealth, to which we give, from which we receive, of which we are all members, rather than of the State as an impersonal dispenser of free doles, or hard levier of taxes.

Here indeed is an ideal which should receive whole-hearted support. We are beginning to realize that we must plan the whole of our society and not merely parts of it, and that in planning parts we must have regard to the fate of the whole. We are learning individually to take a progressively longer view, and in the process the faculty of considered judgment is inculcated. Widespread evidence to-day shows that more and more men and women are becoming fit to share the responsibility for planning the whole course of events in the society in which they move. 